\title{
Maximal Oxygen Levels as an Incremental Exercise to Optimise Individual Training Prescription with the Aim of Rectifying Weaknesses of Elite Algerian Soccer
}

\author{
Mime Mokhtar, Zerf Mohammed*, Hadjar Kherfane Mohamed, Beboucha Wahib \\ Physical Education Institute Laboratory OPAPS, University Abdel Hamid Ibn Badis, Algeria
}

Received October 8, 2019; Revised November 8, 2019; Accepted November 16, 2019

Copyright $(2019$ by authors, all rights reserved. Authors agree that this article remains permanently open access under the terms of the Creative Commons Attribution License 4.0 International License

\begin{abstract}
Purpose: This study aims to provide the Algerian soccer trainers with a systematic method to control and interpret the Algerian soccer's progress. Recommend by soccer studies based on new high-tech to monitor intensity aimed at a competitive superiority of soccer players. Performed based on direct relationship $\mathrm{VO}_{2} \mathrm{max}$, intensity and distance covered in elites match. Methods: to esteem the weaknesses of elite Algerian soccer. This controlled study focused on a yo-yo (IR1) test as a reliable, valid predictor of high-intensity aerobic capacity and $\mathrm{VO}_{2} \max$ athletes levels, which is able to discriminate the differences between player's post-games and player's ability levels. Investigated in this study as a protocol to classify 59 male soccer players under 18 years, labelled on their $\mathrm{VO}_{2} \max$ levels and their relationships with body fat index studies. Results: All statistical procedure results advance the players with high $\mathrm{VO}_{2} \max$ levels up than $59 \mathrm{ml} / \mathrm{kg} / \mathrm{min}$, allows this category of players to record a difference of $8.98 \% \mathrm{VO}_{2}$ max levels, $1160.86 \mathrm{~m}$ of distance covered, $-1,27 \%$ of BFP and $-4,55 \mathrm{ml} / \mathrm{kg} / \mathrm{min}$ of BMI higher compared to the other fewer categories records. Conclusions: Our results approve the Yo-Yo intermittent recovery level 1 (Yo-Yo IR1) test as a valid and reliable test to monitor improvements or decrements of soccer physiological and anthropometrical training concept game demands. It can be concluded in this study as simple and valid data to predict the excess of body fat index on the request aerobic fitness claims for demanding soccer top player profile.
\end{abstract}

Keywords Athletic Body, Intermittent Tests, Training Load, Aerobic Fitness

\section{Introduction}

Nowadays, soccer coaches need all the information and guidance for the success of their teams in training sessions or competitions. Support within the formative feedback able to provide valuable data collection and analysis to interpret the samples physiological profiles [3]. Suggested by the soccer studies through the use of appropriate data tracking tools, such as power output measuring devices, internal load unit measures, and the perception of effort, heart rate, blood lactate, training impulses, and time-motion analysis [31]. Investigated in this study using the Yo-Yo Intermittent Recovery Test (IR1) to estimate the ability of players to perform intense intermittent exercise with a high rate of aerobic and anaerobic energy turnover [17]. Extensively utilised in the literature to monitor the sport-specific intermittent endurance capacity level and training adaptations in soccer players [5]. Despite the fact that the aerobic energy system is highly taxed, with mean and peak heart rates of around 85 and $98 \%$ of maximal values, requiring from top-class players a significant energy intake during a week $[1,33]$. This study focused on a yo-yo (IR1) test as a reliable, valid predictor of high-intensity aerobic capacity and $\mathrm{VO}_{2} \max$ athletes' levels [37]. Checked in this study, based on the aerobic exercise intensity as a significant physiological athletic performance body adaptation to raise aerobic improvement $[11,14,28,35,30]$. Report by preventive body goals studies in the improvements of high-intensity physical training [15] that is more helpful than the moderate-intensity to reduce the effects of body composition [19]. Targeted in this study based on Yo-yo test $\mathrm{VO}_{2} \max$ data levels as a powerful strategy to inspect the adequate fitness concomitant with ideal body composition among our sample [36]. Admitted in this study, as a valid tool for predicting the excess of body weight on the request aerobic fitness profile through soccer players [14,18,20,25,27,32]. 


\section{Material and Methods}

\subsection{Approximation Method}

The present study compared the improvements of soccer players under 18 years from Algerian elite S-League players using the yo-yo intermittent test. Allowed by Yo-Yo IR level 1 (Yo-Yo IR1) as a simple and valid way to obtain important information of an individual's capacity to perform repeated intense exercise and to examine changes in performance [36] associated with body composition (BMI \& BFP), weight loss goals [4,10] and athletes' aerobic fitness programs [20,28,29,31,37].

\subsection{Participants}

A total of 59 male elite players, aged around 17.65 (years) \pm 0.39 took part in the present study, season 2016 to 2017, from division one league Oran. Examined in the parameters (anthropometric and physiological), during the transition phase of the Algerian Championship. Listed in Table 1, according to their $\mathrm{VO}_{2}$ max levels derived from Yo-yo test norms, as scientists approached helpful soccer and active people gain the desired body-weight goals or body composition, required for athletic success performance, appearance and health [23].

Table 1. Present the evaluated $\mathrm{VO}_{2}$ max levels of samples classified by the yo-yo intermittent test data norms

\begin{tabular}{|c|c|c|c|c|c|c|c|c|}
\hline & & $\mathrm{N}$ & Mean & $\mathrm{SD}$ & Levine Statistic & $\mathrm{P} \leq 0.05$ & Anova & $\mathrm{P} \leq 0.05$ \\
\hline \multirow{5}{*}{ BFP (\%) } & $\mathrm{VO}_{2} \max <50 \mathrm{ml} / \mathrm{kg} / \mathrm{min}$ & 10 & 12.23 & 1.12 & \multirow{5}{*}{0.841} & \multirow{5}{*}{0.477} & \multirow{5}{*}{6,409} & \multirow{5}{*}{0.00} \\
\hline & $\mathrm{VO}_{2} \max >53 \mathrm{ml} / \mathrm{kg} / \mathrm{min}$ & 20 & 12.11 & 3.37 & & & & \\
\hline & $\mathrm{VO}_{2} \max >56 \mathrm{ml} / \mathrm{kg} / \mathrm{min}$ & 18 & 10,96 & 1,05 & & & & \\
\hline & $\mathrm{VO}_{2} \max >59 \mathrm{ml} / \mathrm{kg} / \mathrm{min}$ & 11 & 8,85 & 0,92 & & & & \\
\hline & Total & 59 & 11.17 & 2.43 & & & & \\
\hline \multirow{5}{*}{$\begin{array}{c}\text { BMI } \\
\left(\mathrm{kg} / \mathrm{m}^{2}\right)\end{array}$} & $\mathrm{VO}_{2} \max <50 \mathrm{ml} / \mathrm{kg} / \mathrm{min}$ & 10 & 24,01 & 1,09 & \multirow{5}{*}{1395} & \multirow{5}{*}{0,254} & \multirow{5}{*}{18436} & \multirow{5}{*}{0,00} \\
\hline & $\mathrm{VO}_{2} \max >53 \mathrm{ml} / \mathrm{kg} / \mathrm{min}$ & 20 & 22,36 & 1,71 & & & & \\
\hline & $\mathrm{VO}_{2} \max >56 \mathrm{ml} / \mathrm{kg} / \mathrm{min}$ & 18 & 21,36 & 1,47 & & & & \\
\hline & $\mathrm{VO}_{2} \max >59 \mathrm{ml} / \mathrm{kg} / \mathrm{min}$ & 11 & 19,45 & 1,22 & & & & \\
\hline & Total & 59 & 21.79 & 2.02 & & & & \\
\hline \multirow{5}{*}{$\begin{array}{c}\mathrm{VO}_{2} \mathrm{MAX} \\
(\mathrm{ml} / \mathrm{kg} / \mathrm{min})\end{array}$} & $\mathrm{VO}_{2} \max <50 \mathrm{ml} / \mathrm{kg} / \mathrm{min}$ & 10 & 51,32 & 1,63 & \multirow{5}{*}{1688} & \multirow{5}{*}{0,180} & \multirow{5}{*}{75029} & \multirow{5}{*}{0,00} \\
\hline & $\mathrm{VO}_{2} \max >53 \mathrm{ml} / \mathrm{kg} / \mathrm{min}$ & 20 & 54,64 & 1,64 & & & & \\
\hline & $\mathrm{VO}_{2} \max >56 \mathrm{ml} / \mathrm{kg} / \mathrm{min}$ & 18 & 56,77 & 1,17 & & & & \\
\hline & $\mathrm{VO}_{2} \max >59 \mathrm{ml} / \mathrm{kg} / \mathrm{min}$ & 11 & 60,30 & 1,23 & & & & \\
\hline & Total & 59 & 55.78 & 3.16 & & & & \\
\hline \multirow{5}{*}{$\begin{array}{l}\text { Distance } \\
\text { (m) }\end{array}$} & $\mathrm{VO}_{2} \max <50 \mathrm{ml} / \mathrm{kg} / \mathrm{min}$ & 10 & 1773,33 & 176,24 & \multirow{5}{*}{2512} & \multirow{5}{*}{0,458} & \multirow{5}{*}{52301} & \multirow{5}{*}{0,00} \\
\hline & $\mathrm{VO}_{2} \max >53 \mathrm{ml} / \mathrm{kg} / \mathrm{min}$ & 20 & 2174,57 & 199,89 & & & & \\
\hline & $\mathrm{VO}_{2} \max >56 \mathrm{ml} / \mathrm{kg} / \mathrm{min}$ & 18 & 2429,62 & 142,49 & & & & \\
\hline & $\mathrm{VO}_{2} \max >59 \mathrm{ml} / \mathrm{kg} / \mathrm{min}$ & 11 & 2934,19 & 366,27 & & & & \\
\hline & Total & 59 & 2326.00 & 425.49 & & & & \\
\hline \multirow{5}{*}{$\begin{array}{l}\text { Height } \\
(\mathrm{cm})\end{array}$} & $\mathrm{VO}_{2} \max <50 \mathrm{ml} / \mathrm{kg} / \mathrm{min}$ & 10 & 172,00 & 4,71 & \multirow{5}{*}{0,715} & \multirow{5}{*}{0,547} & \multirow{5}{*}{1781} & \multirow{5}{*}{0,16} \\
\hline & $\mathrm{VO}_{2} \max >53 \mathrm{ml} / \mathrm{kg} / \mathrm{min}$ & 20 & 174.60 & 4.66 & & & & \\
\hline & $\mathrm{VO}_{2} \max >56 \mathrm{ml} / \mathrm{kg} / \mathrm{min}$ & 18 & 176.6111 & 4.23 & & & & \\
\hline & $\mathrm{VO}_{2} \max >59 \mathrm{ml} / \mathrm{kg} / \mathrm{min}$ & 11 & 174.6364 & 7.13 & & & & \\
\hline & Total & 59 & 174.7797 & 5.19 & & & & \\
\hline \multirow{5}{*}{$\begin{array}{l}\text { Weight } \\
(\mathrm{kg})\end{array}$} & $\mathrm{VO}_{2} \max <50 \mathrm{ml} / \mathrm{kg} / \mathrm{min}$ & 10 & 67,1700 & 8,22 & \multirow{5}{*}{0,140} & \multirow{5}{*}{0,936} & \multirow{5}{*}{1650} & \\
\hline & $\mathrm{VO}_{2} \max >53 \mathrm{ml} / \mathrm{kg} / \mathrm{min}$ & 20 & 63.2050 & 7.43 & & & & \\
\hline & $\mathrm{VO}_{2} \max >56 \mathrm{ml} / \mathrm{kg} / \mathrm{min}$ & 18 & 63.0111 & 7.88 & & & & 0,19 \\
\hline & $\mathrm{VO}_{2} \max >59 \mathrm{ml} / \mathrm{kg} / \mathrm{min}$ & 11 & 59.6091 & 7.84 & & & & \\
\hline & Total & 59 & 63.1475 & 7.91 & & & & \\
\hline
\end{tabular}




\subsection{Tests and Protocol}

As the objective of this controlled study is aimed to provide the Algerian soccer trainers with a valuable method to control and interpret the Algerian soccer's progress, in the lack of modern soccer coaching tools. We centred on Yo-Yo intermittent endurance test level 1, in addition to the formula of body index fat or fatness. Reported in several studies as a practical measure that does not require any skilful involvement of sophisticated equipment [7].

\subsubsection{Yo-yo Intermittent Test}

The Yo-yo intermittent recovery test (level 1 test): developed to measure the player's ability to repeat high-intensity aerobic work. Admitted in soccer studies as a more reliable, valid indicator of the individual's status aerobic capacity, directly correlated to the physical demands and physiological cardiovascular function. The Yo-yo IR1 incorporates $2 \times 20 \mathrm{~m}$ shuttles interspersed with $10 \mathrm{~s}$ of active recovery with speed increases regulated by audio signals from a CD player. Participants continue until they can no longer maintain the speed imposed by audio signals, and the distance covered at that moment is the test result [24]. The equations for calculating V02max (YYIR1 test: V02max $(\mathrm{mL} * \mathrm{~kg}-1 * \min -1)=\mathrm{IR} 1$ distance $(\mathrm{m}) \times$ $0.0084+36.4)$.

\subsubsection{Anthropometrics' Measurement}

Body height $(\mathrm{BH})$ and body weight $(\mathrm{BW})$ : Standing height (m) was measured without shoes to the nearest 0.1 $\mathrm{cm}$ using a portable stadiometer (seca 213), and weight (kg) was measured to the nearest $0.1 \mathrm{~kg}$ by a digital scale (Tanita model number TBF 410). BMI was calculated by weight in $\mathrm{kg}$ divided by the square of height in meters (m2).

\subsubsection{Body Fat Percentage (BFP)}

In the current study, BFP was assessed by BIA methods using Biodynamics-310. Support by Lin Wang and Stanley Sai-chuen Hui (2015) as a valid tool to estimate BFP [10]. Reported by its significant positive correlation with DXA Measurement.

\subsection{Statistical Analysis}

Data analysis was performed using SPSS 22.0 for Windows (32- bit) (IBM, Armonk, NY, USA). Descriptive statistics were adopted to describe the anthropometric parameters and for performance presentation of the entire sample. Data collected studies show the homogeneity of the sample by the power of the Levine test. ANOVA was directed to identify the significant effect of V02max categories on performance relative to the optional athletics body composition. LSD post hot tests were accompanied to show the mean difference between the groups via variables chosen to study. The relationship between the variables was checked using Pearson correlations (r). All statistical significance fixes at $\mathrm{p} 0.05$.

\section{Results}

Based on the study design, tests, protocol and statistics applied. Our results in Table 1 and figure 1 show the homogeneity of the collected sample in all variables entered. Certified by the significance of Levine's statistic. The opposite of ANOVA one-way that is significant in the distance covered, BMI and BFP, the contrary of weight and height. Enabling users, the calculation of the LSD to classify the difference between groups listed in Table 3 . Recorded in favour of the players with high $\mathrm{VO}_{2}$ max levels and low body fat or composition, competent to achieve a more significant distance covered in this intermittent test. Interpret by users through the effect of the body fat, not body weight as the principal factor, influencing aerobic players' performance [9]. Upkeep in this study by the validity of Yo-Yo IR level 1 (Yo-Yo IR1) as a simple and valid way to obtain important information of an individual's capacity to perform repeated intense exercise and to examine changes in performance [17]. Detailed in the present via Tables 2 and 3. Records for the advantage of players with $\mathrm{VO}_{2} \max$ up to $59 \mathrm{ml} / \mathrm{kg} / \mathrm{min}$, permitting this player to top score a difference of $8.98 \%\left(\mathrm{Vo}_{2} \mathrm{max}\right)$, $1160.86 \mathrm{~m}$ of distance covered (-1.27\%) of BFP and (-4.55 $\mathrm{ml} / \mathrm{kg} / \mathrm{min}$ ) of BMI, superior to other $\mathrm{VO}_{2} \mathrm{max}$ categories. Shown in a recent study as an advantage of $11 \% \mathrm{Vo}_{2} \max$ increases, enabling players to growth their intensity match by $5 \%$ and the distance covered by $1800 \mathrm{~m}$ [11]. 


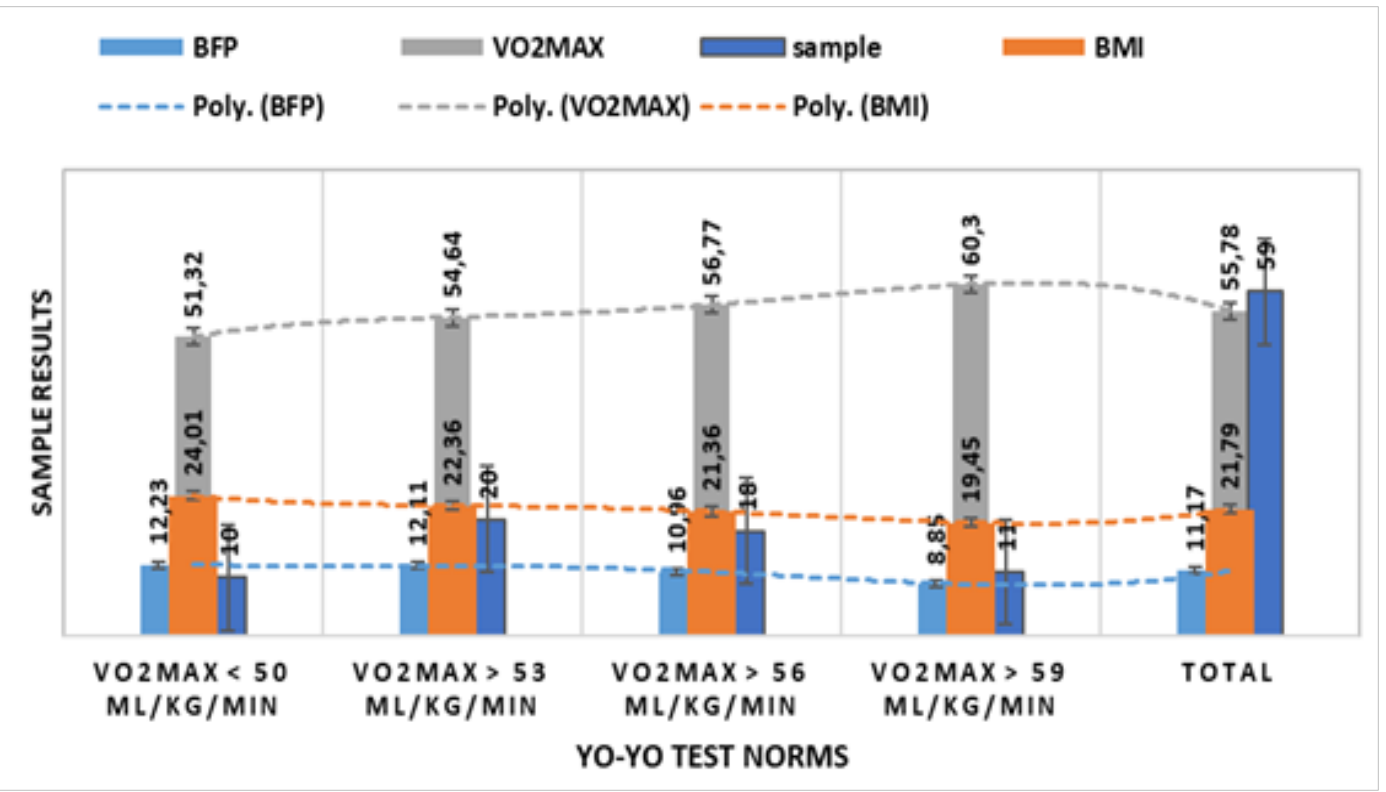

Figure 1. Present the characteristics of the sample based on $\mathrm{VO}_{2}$ max levels as data analysis derive from Yo-yo test norms

Table 2. Present the Pearson correlation $\mathrm{VO}_{2}$ max levels and distance covered versus body fat index applied in this study

\begin{tabular}{|c|c|c|c|c|}
\hline Pearson Correlation & BFP & BMI & $\mathrm{VO}_{2} \mathrm{MAX}$ & Distance \\
\hline $\mathrm{VO}_{2} \mathrm{MAX}$ & $-0.78^{* *}$ & $-0.76^{* *}$ & 1 & $0.95^{* *}$ \\
\hline Distance & $-0.72^{* *}$ & $-0.70^{* *}$ & $0.95^{* *}$ & 1 \\
\hline $\mathrm{N}=59$ & $\mathrm{P} \leq 0.05^{* *}$. Correlation is significant at the 0.01 level (2-tailed) \\
\hline
\end{tabular}

Table 3. Show the Multiple Comparisons between $\mathrm{VO}_{2}$ max levels under the variables studies

\begin{tabular}{|c|c|c|c|c|c|}
\hline Dependent Variable & (I) $\mathrm{VO}_{2} \mathrm{MAX}$ Levels & (J) VO2MAX Levels & Mean Difference (I-J) & Std. Error & $\mathrm{P} \leq 0.05$ \\
\hline \multirow{12}{*}{$\mathrm{BFP} \%$} & \multirow{3}{*}{$\mathrm{VO}_{2} \max <50 \mathrm{ml} / \mathrm{kg} / \mathrm{min}$} & $\mathrm{VO}_{2} \max >53 \mathrm{ml} / \mathrm{kg} / \mathrm{min}$ & 0.13 & 0.83 & 0.87 \\
\hline & & $\mathrm{VO}_{2} \max >56 \mathrm{ml} / \mathrm{kg} / \mathrm{min}$ & 1.27 & 0.84 & 0.14 \\
\hline & & $\mathrm{VO}_{2} \max >59 \mathrm{ml} / \mathrm{kg} / \mathrm{min}$ & $3,38^{*}$ & 0,93 & 0,00 \\
\hline & \multirow{3}{*}{$\mathrm{VO}_{2} \max >53 \mathrm{ml} / \mathrm{kg} / \mathrm{min}$} & $\mathrm{VO}_{2} \max <50 \mathrm{ml} / \mathrm{kg} / \mathrm{min}$ & -0.12 & 0.83 & 0.87 \\
\hline & & $\mathrm{VO}_{2} \max >56 \mathrm{ml} / \mathrm{kg} / \mathrm{min}$ & 1.14 & 0.69 & 0.11 \\
\hline & & $\mathrm{VO}_{2} \max >59 \mathrm{ml} / \mathrm{kg} / \mathrm{min}$ & $3.25^{*}$ & 0.81 & 0.00 \\
\hline & \multirow{3}{*}{$\mathrm{VO}_{2} \max >56 \mathrm{ml} / \mathrm{kg} / \mathrm{min}$} & $\mathrm{VO}_{2} \max <50 \mathrm{ml} / \mathrm{kg} / \mathrm{min}$ & -1.27 & 0.85 & 0.13 \\
\hline & & $\mathrm{VO}_{2} \max >53 \mathrm{ml} / \mathrm{kg} / \mathrm{min}$ & -1.14 & 0.69 & 0.11 \\
\hline & & $\mathrm{VO}_{2} \max >59 \mathrm{ml} / \mathrm{kg} / \mathrm{min}$ & $2.12^{*}$ & 0.82 & 0.01 \\
\hline & \multirow{3}{*}{$\mathrm{VO}_{2} \max >59 \mathrm{ml} / \mathrm{kg} / \mathrm{min}$} & $\mathrm{VO}_{2} \max <50 \mathrm{ml} / \mathrm{kg} / \mathrm{min}$ & $-3,38^{*}$ & 0,93 & 0,00 \\
\hline & & $\mathrm{VO}_{2} \mathrm{max}>53 \mathrm{ml} / \mathrm{kg} / \mathrm{min}$ & $-3,25^{*}$ & 0,81 & 0,00 \\
\hline & & $\mathrm{VO}_{2} \max >56 \mathrm{ml} / \mathrm{kg} / \mathrm{min}$ & $-2,12^{*}$ & 0,82 & 0,01 \\
\hline \multirow{9}{*}{$\operatorname{BMI}\left(\mathrm{kg} / \mathrm{m}^{2}\right)$} & \multirow{3}{*}{$\mathrm{VO}_{2} \max <50 \mathrm{ml} / \mathrm{kg} / \mathrm{min}$} & $\mathrm{VO}_{2} \max >53 \mathrm{ml} / \mathrm{kg} / \mathrm{min}$ & $1,64^{*}$ & 0,56 & 0,00 \\
\hline & & $\mathrm{VO}_{2} \max >56 \mathrm{ml} / \mathrm{kg} / \mathrm{min}$ & $2,64^{*}$ & 0,57 & 0,00 \\
\hline & & $\mathrm{VO}_{2} \max >59 \mathrm{ml} / \mathrm{kg} / \mathrm{min}$ & $4,55^{*}$ & 0,64 & 0,00 \\
\hline & \multirow{3}{*}{$\mathrm{VO}_{2} \max >53 \mathrm{ml} / \mathrm{kg} / \mathrm{min}$} & $\mathrm{VO}_{2} \max <50 \mathrm{ml} / \mathrm{kg} / \mathrm{min}$ & $-1.64^{*}$ & 0.56 & 0.05 \\
\hline & & $\mathrm{VO}_{2} \max >56 \mathrm{ml} / \mathrm{kg} / \mathrm{min}$ & $1.02^{*}$ & 0.47 & 0.04 \\
\hline & & $\mathrm{VO}_{2} \max >59 \mathrm{ml} / \mathrm{kg} / \min$ & $2.91^{*}$ & 0.55 & 0.00 \\
\hline & \multirow{3}{*}{$\mathrm{VO}_{2} \max >56 \mathrm{ml} / \mathrm{kg} / \mathrm{min}$} & $\mathrm{VO}_{2} \max <50 \mathrm{ml} / \mathrm{kg} / \mathrm{min}$ & $-2.64^{*}$ & 0.57 & 0.00 \\
\hline & & $\mathrm{VO}_{2} \max >53 \mathrm{ml} / \mathrm{kg} / \mathrm{min}$ & $-1.02^{*}$ & 0.47 & 0.04 \\
\hline & & $\mathrm{VO}_{2} \max >59 \mathrm{ml} / \mathrm{kg} / \mathrm{min}$ & $1.91^{*}$ & 0.56 & 0.00 \\
\hline
\end{tabular}




\begin{tabular}{|c|c|c|c|c|c|}
\hline & \multirow{3}{*}{$\mathrm{VO}_{2} \max >59 \mathrm{ml} / \mathrm{kg} / \mathrm{min}$} & $\mathrm{VO}_{2} \max <50 \mathrm{ml} / \mathrm{kg} / \mathrm{min}$ & $-4.55^{*}$ & 0.64 & 0.00 \\
\hline & & $\mathrm{VO}_{2} \max >53 \mathrm{ml} / \mathrm{kg} / \mathrm{min}$ & $-2.91^{*}$ & 0.55 & 000 \\
\hline & & $\mathrm{VO}_{2} \max >56 \mathrm{ml} / \mathrm{kg} / \mathrm{min}$ & $-1.91^{*}$ & 0.56 & 0.00 \\
\hline \multirow{12}{*}{$\begin{array}{c}\mathrm{VO}_{2} \mathrm{MAX} \\
(\mathrm{ml} / \mathrm{kg} / \mathrm{min})\end{array}$} & \multirow{3}{*}{$\mathrm{VO}_{2} \max <50 \mathrm{ml} / \mathrm{kg} / \mathrm{min}$} & $\mathrm{VO}_{2} \max >53 \mathrm{ml} / \mathrm{kg} / \mathrm{min}$ & $-3.32^{*}$ & 0.56 & 0.00 \\
\hline & & $\mathrm{VO}_{2} \max >56 \mathrm{ml} / \mathrm{kg} / \mathrm{min}$ & $-5.45^{*}$ & 0.57 & 0.00 \\
\hline & & $\mathrm{VO}_{2} \max >59 \mathrm{ml} / \mathrm{kg} / \mathrm{min}$ & $-8.98^{*}$ & 0.63 & 0.00 \\
\hline & & $\mathrm{VO}_{2} \max <50 \mathrm{ml} / \mathrm{kg} / \mathrm{min}$ & $3.32^{*}$ & 0.56 & 0.00 \\
\hline & $\mathrm{VO}_{2} \max >53 \mathrm{ml} / \mathrm{kg} / \mathrm{min}$ & $\mathrm{VO}_{2} \max >56 \mathrm{ml} / \mathrm{kg} / \mathrm{min}$ & $-2.13^{*}$ & 0.47 & 0.00 \\
\hline & & $\mathrm{VO}_{2} \max >59 \mathrm{ml} / \mathrm{kg} / \mathrm{min}$ & $-5.66^{*}$ & 0.54 & 0.00 \\
\hline & & $\mathrm{VO}_{2} \max <50 \mathrm{ml} / \mathrm{kg} / \mathrm{min}$ & $5.45^{*}$ & 0.57 & 0.00 \\
\hline & $\mathrm{VO}_{2} \max >56 \mathrm{ml} / \mathrm{kg} / \mathrm{min}$ & $\mathrm{VO}_{2} \max >53 \mathrm{ml} / \mathrm{kg} / \mathrm{min}$ & $2.13^{*}$ & 0.47 & 0.00 \\
\hline & & $\mathrm{VO}_{2} \max >59 \mathrm{ml} / \mathrm{kg} / \mathrm{min}$ & $-3.53^{*}$ & 0.55 & 0.00 \\
\hline & & $\mathrm{VO}_{2} \max <50 \mathrm{ml} / \mathrm{kg} / \mathrm{min}$ & $8,98^{*}$ & 0,63 & 0,00 \\
\hline & $\mathrm{VO}_{2} \max >59 \mathrm{ml} / \mathrm{kg} / \mathrm{min}$ & $\mathrm{VO}_{2} \max >53 \mathrm{ml} / \mathrm{kg} / \mathrm{min}$ & $5,66^{*}$ & 0,54 & 0,00 \\
\hline & & $\mathrm{VO}_{2} \max >56 \mathrm{ml} / \mathrm{kg} / \mathrm{min}$ & $3,53^{*}$ & 0,55 & 0,00 \\
\hline & & $\mathrm{VO}_{2} \max >53 \mathrm{ml} / \mathrm{kg} / \mathrm{min}$ & $-401,24^{*}$ & 86,22 & 0,00 \\
\hline & $\mathrm{VO}_{2} \max <50 \mathrm{ml} / \mathrm{kg} / \mathrm{min}$ & $\mathrm{VO}_{2} \max >56 \mathrm{ml} / \mathrm{kg} / \mathrm{min}$ & $-656,29^{*}$ & 87,79 & 0,00 \\
\hline & & $\mathrm{VO}_{2} \max >59 \mathrm{ml} / \mathrm{kg} / \mathrm{min}$ & $-1160,86^{*}$ & 97,26 & 0,00 \\
\hline & & $\mathrm{VO}_{2} \max <50 \mathrm{ml} / \mathrm{kg} / \mathrm{min}$ & $401.24^{*}$ & 86.22 & 0.00 \\
\hline & $\mathrm{VO}_{2} \max >53 \mathrm{ml} / \mathrm{kg} / \mathrm{min}$ & $\mathrm{VO}_{2} \max >56 \mathrm{ml} / \mathrm{kg} / \mathrm{min}$ & $-255.06^{*}$ & 72.32 & 0.00 \\
\hline Distance & & $\mathrm{VO}_{2} \max >59 \mathrm{ml} / \mathrm{kg} / \mathrm{min}$ & $-759.63^{*}$ & 83.56 &, 000 \\
\hline (m) & & $\mathrm{VO}_{2} \max <50 \mathrm{ml} / \mathrm{kg} / \mathrm{min}$ & $656.29^{*}$ & 87.79 & 0.00 \\
\hline & $\mathrm{VO}_{2} \max >56 \mathrm{ml} / \mathrm{kg} / \mathrm{min}$ & $\mathrm{VO}_{2} \max >53 \mathrm{ml} / \mathrm{kg} / \mathrm{min}$ & $255.06^{*}$ & 72.32 & 0.00 \\
\hline & & $\mathrm{VO}_{2} \max >59 \mathrm{ml} / \mathrm{kg} / \mathrm{min}$ & $-504.57^{*}$ & 85.19 & 0.00 \\
\hline & & $\mathrm{VO}_{2} \max <50 \mathrm{ml} / \mathrm{kg} / \mathrm{min}$ & $1160.86^{*}$ & 97.26 & 0.00 \\
\hline & $\mathrm{VO}_{2} \max >59 \mathrm{ml} / \mathrm{kg} / \mathrm{min}$ & $\mathrm{VO}_{2} \max >53 \mathrm{ml} / \mathrm{kg} / \mathrm{min}$ & $759.63^{*}$ & 83.56 & 0.00 \\
\hline & & $\mathrm{VO}_{2} \max >56 \mathrm{ml} / \mathrm{kg} / \mathrm{min}$ & $504.57^{*}$ & 85.19 & 0.00 \\
\hline
\end{tabular}

*. The mean difference is significant at the 0.05 level.

Established in this study by Yo-Yo IR level 1 (Yo-Yo IR1) test $\mathrm{VO}_{2}$ max levels and players' distance covered and their strong negative inverse correlations with fat index calculated. Set in this study as a complicated body's function to sustenance the high-intensity work [18] for long periods [13]. Demanding from Algerian players to increase both energy systems to maximise fat oxidation rates and total metabolic demand [34].

Informed by this trial study, as a simple process to select demand exercise intensity able to enhance fat oxidation [30] and promote weight loss [5].Highlighted in this study based on the significant correlations recorded between the player's fat index and the total work time associated with the distance covered in the yo-yo test [3]. Advanced by Asok Kumar Ghosh as the best measure of endurance performance to determine the well-trained player [12].

\section{Discussion}

Support low levels of $\mathrm{VO}_{2} \max$ have been established as an independent risk factor for the overweight. Required from our coaches to develop an intervention that targets weight management. As a negative process, Algerian coaches' selection practises [35]. Aimed by Algerian scientists via the application of multidisciplinary scientific and highly expert approach with available scientific findings and inferences, skilful knowledge, intuition and experience to decide the player selection and training proceed and progress [36]. The case of this study claim by Yo-Yo IR level 1 (Yo-Yo IR1) test as a simple and valid method to obtain important information of an individual's capacity to perform repeated intense exercise and to examine changes in performance [30-32-37]. Confirmed in this study as a valid sensitive measure not only to examine maximal activation of the aerobic system but also its associations with fat index and their relations with changes in performance. Suggesting Yo-yo IR level 1 (Yo-Yo IR1) to be the best measure of endurance performance during a soccer game and training. Its data of $\mathrm{VO}_{2}$ max performance confirmed the necessity to be trained above $\sim 60 \%$ of $\mathrm{VO}_{2} \max$, likely to improve both energy systems (aerobic and anaerobic) [2]. Admitted by soccer match analysis as a positive relationship between the Yo-Yo IR1 test result and 
match performance of top-class soccer referees $[15,20,27,33]$. Where a $31 \%$ increase in Yo-Yo IR1 performance after a 12-week training period was associated with a $23 \%$ higher intensity workload during a match. The case of this study records in the profits of the group above $+59 \%$ of $\mathrm{VO}_{2}$ max as effective physiological load responses ready to improve individuals' training state (body goals and performance) [33,38]. Backed by Małgorzata Fortuna et al., via energy expenditure directly associated with the total distance and player's work intensity [18]. Qualified by similar studies through the impacts of training loads and their relationship with the excess of body fat, and its consequences on physical performance correlated with anthropometric dimensions (shape or type) [8]. Upkeep by soccer literature via excess body fat that slows down the athlete's speed and affects endurance [21]. Admitted by present in the interest of players with high $\mathrm{VO}_{2}$ max levels up than $59 \mathrm{ml} / \mathrm{kg} / \mathrm{min}$, allows this category of players to record a difference of $8.98 \% \mathrm{VO}_{2} \mathrm{max}$ levels, $1160.86 \mathrm{~m}$ of distance covered, $-1,27 \%$ of BFP and $-4,55 \mathrm{ml} / \mathrm{kg} / \mathrm{min}$ of BMI higher than the other smaller amount categories. Shown in this study as benefit data analysis to design the proper individual's program, adjust based on the player physiological responses, which must attend high-intensity aerobic capacity and $\mathrm{VO}_{2}$ max recruitment supervision as training concepts [4]. Reported by the validity of Yo-Yo IR tests shown in this study as a sensitive measure to inspect the changes in performance allied to ideal body weight fat index [7]. Established in this study by Yo-yo IR level 1 (Yo-Yo IR1) $\mathrm{VO}_{2} \max$ data. To be maintained at up to $59 \%$ of $\mathrm{VO}_{2} \mathrm{max}$ as advantageous fat max intensity-training competencies to perform the physical and physiological player status improvements. Asserted by J Hoff et al., as representatives load specific training to improve the various components of fitness in all its aspects and levels [16]. Appreciate by Hassane Zouhal et al., as a significant training body adaptation that increases aerobic and anaerobic fitness [15]. Due to the enhancement of skeletal muscle-fat oxidation and glucose tolerance concomitant with body composition management [26]. Suggested in this study as informative data analysis inspected to assess the complete picture of player abilities [19]. Built on Yo-yo $\mathrm{VO}_{2}$ max data levels as formative control tools of training progress [37]. Presenting by Yo-Yo IR level 1 (Yo-Yo IR1) test as a simple and valid way to obtain important information of an individual's capacity to perform repeated intense exercise and to examine changes in performance relative to change of players body fat index $[13,22,23,34,35]$.

\section{Conclusions}

The present study confirms the Yo-Yo IR level 1 (Yo-Yo IR1) test as an incremental protocol of accurate information to assess the completed picture of players' aerobic abilities. Report as a valid alternative approach to adjust physiological variables based on inter-individual body fat size difference. The case of this study support by the players' performance in Yo-Yo IR level 1 and their relationships with body fat index studies. Reported in this study in the interest of players with high $\mathrm{VO}_{2}$ max levels up than $59 \mathrm{ml} / \mathrm{kg} / \mathrm{min}$. Electives to cause significant differences about $8.98 \% \mathrm{VO}_{2}$ max levels, $1160.86 \mathrm{~m}$ of distance achieved, $-1,27 \%$ of BFP and $-4,55 \mathrm{ml} / \mathrm{kg} / \mathrm{min}$ of BMI higher than its reduced. Let researchers recommending Algerian coaches to take Yo-yo test $\mathrm{VO}_{2} \max$ data norms. As a systematic approach to optimise individual training prescriptions with the aim of rectifying the weaknesses of their players.

\section{REFERENCES}

[1] Almeida MA, Silva SPR, Pedrinelli A, Hernandez A.J (2018). Aerobic fitness in professional soccer players after anterior cruciate ligament reconstruction. PLoS ONE, 3, e0194432. Doi: https://doi.org/10.1371/journal.pone.01944 32

[2] Boutcher, S.H. (2011). High-Intensity Intermittent Exercise and Fat Loss. J Obes, 868305. Doi: http://dx.doi.org/10.11 $55 / 2011 / 868305$

[3] Brink MS \& Frencken W.G. P. (2018). Formative feedback for the coach reduces mismatch between coach and players' perceptions of exertion. Science and Medicine in Football, 0 (0), 1-7. doi:10.1080/24733938.2018.1451651

[4] Chamari K, Hachana Y, Ahmed YB, et al. (2004). Field and laboratory testing in young elite soccer players. British Journal of Sports Medicine, 38, 191-196. Doi: http://dx.do i.org/10.1136/bjsm.2002.004374

[5] Coelho-e-Silva MG, Filipe S, João-Valente-dos S, Robert M. M. (2016). Assessment of biological maturation in adolescent athletes: application of different methods with soccer and hockey players. Portuguese: University the Colomba

[6] David J.M, James E.Z, William S.Q, Robert C.M. (2011). Athletic and Sport Issues in Musculoskeletal Rehabilitation. St. Louis, Mo: Elsevier/Saunders.

[7] Dawes J J, Orr R M, Siekaniec CL, Vanderwoude AA and Pope R. (2016). Associations between anthropometric characteristics and physical performance in male law enforcement officers: a retrospective cohort study. Ann Occup Environ Med, 28 (26), 1-7. Doi: 10.1186/s40557-01 6-0112-5

[8] Deurenberg P, Weststrate JA, Seidell JC. (1991). Body mass index as a measure of body fatness: age- and sex-specific prediction formulas. Br J Nutr, 65 (2), 105-14. Retrieved from https://www.ncbi.nlm.nih.gov/pubmed/2043597

[9] Dolański B, Rompa P, Hongyou L, Wasielewski K, \& Szwarc A. (2018). Time-motion characteristics of match-play in elite Polish youth soccer players of various playing positions. Baltic Journal of Health and Physical Activity, 10 (3), 115-123. Doi:10.29359/BJHPA.10.3.13.

[10] Lin W and Stanley S-C. H. (2015). Validity of Four 
Commercial Bioelectrical Impedance Scales in Measuring Body Fat among Chinese Children and Adolescents BioMed Research International, 2015(8). http://dx.doi.org/ $10.1155 / 2015 / 614858$

[11] Evangelos B, Lefteris M, Aristotelis G, Ioannis, G, Natalia, K. (2016). Aerobic and Anaerobic Capacity of Professional Soccer Players in Annual Macrocycle. Journal of Physical Education and Sport (JPES), 16 (2), 527-533. doi: 10.7752 /jpes.2016.02082

[12] Ghosh AK. (2004). Anaerobic Threshold Its Concept and Role in Endurance Sport. Malays J Med Sci, 11 (1), 24-36. Retrieved fromhttps://www.ncbi.nlm.nih.gov/pmc/articles/ PMC3438148/

[13] Gonçalves ECA, and Silva DAS. (2016). Factors associated with low levels of aerobic fitness among adolescents. Revista Paulista de Pediatria, 2. Doi:http://dx.doi.org/10.10 16/j.rppede.2015.06.025

[14] Halson SL (2014). Monitoring Training Load to Understand Fatigue in Athletes. Sports Med, 44 (Suppl 2), 139-147. Doi:https://dx.doi.org/10.1007\%2Fs40279-014-0253-z

[15] Hoff J, Wisløff U, Engen L C, Kemi O J, Helgerud J. (2002). Soccer specific aerobic endurance training. British Journal of Sports Medicine (BJSM), 36 (3), 218-221. Doi: http://d x.doi.org/10.1136/bjsm.36.3.218

[16] Insel P, Ross D, McMahon K, et al. (2016). Nutrition. US: Jones and Bartlett Publishers.

[17] Jemni M, Prince M S and Baker JS. (2018). Assessing Cardiorespiratory Fitness of Soccer Players: Is Test Specificity the Issue?-A Review. Sports Medicine, 4 (28), 1-18. Doi:1186/s40798-018-0134-3

[18] Małgorzata F, Jacek, Tomasz Z, Dagmara P and Iwona D. (2018). Estimation of evaluation some spirometric's parameters of football players during preparation period. Journal of Education, Health and Sport., 8 (6), 69-79. doi:http://dx.doi.org/10.5281/zenodo. 1252282

[19] McMillan K, Helgerud J, Macdonald R, \& Hoff J. (2005). Physiological adaptations to soccer specific endurance training in professional youth soccer players. British Journal of Sports Medicine, 39 (5), 273-277. Doi:http://dx.doi.org/10.1136/bjsm.2004.012526

[20] Mondal H, Mishra SP. (2017). Effect of BMI, Body Fat Percentage and Fat Free Mass on Maximal Oxygen Consumption in Healthy Young Adults. J Clin Diagn Res, 11 (6), CC17-CC20. Doi:10.7860/JCDR/2017/25465.1003 9

[21] Murphy A, Reilly T, and Spinks W. (2002). Science and Football IV. London: Routledge.

[22] Murphy JG, Murphy MA. (2012). Textbook, Mayo Clinic Cardiology. UK: Oxford University Press.

[23] Radovanović S, Kocić S, Gajović G, Radević S, Milosavljević M, Nićiforović J. (2014). The impact of body weight on aerobic capacity. Med Glas (Zenica), 11 (1), 204-9. Retrieved fromhttps://www.ncbi.nlm.nih.gov/pubm ed/24496365

[24] Reilly T. (2003). Advances in Sport, Leisure and Ergonomics. London: Routledge.

[25] Sathi A. (2016). Cognitive (Internet of) Things
Collaboration to Optimize Action. New York: Palgrave Macmillan US: Palgrave Macmillan.

[26] Sawai A, Mathis B.J., Natsui H., Zaboronok A., Mitsuhashi R., Warashina Y., Mesaki N., Shiraki H., Watanabe K.. (2018). Risk of female athlete triad development in Japanese collegiate athletes is related to sport type and competitive level. International Journal of Women's Health, 10, 671-687. Doi: https://doi.org/10.2147/IJWH.S175446

[27] Shete AN, Bute SS and Deshmukh P.R. (2014). A Study of $\mathrm{VO}_{2} \mathrm{Max}$ and Body Fat Percentage in Female Athletes. J Clin Diagn Res, 8 (12), BC01-BC03. Doi:10.7860/JCDR/ 2014/10896.5329

[28] Simini F \& Bertemes-Filho P. (2018). Bioimpedance in Biomedical Applications and Research. Cham: Springer International Publishing: Springer.

[29] Statler S. (2016). Beacon Technologies: The Hitchhiker's Guide to the Beacosystem. Berkeley, CA: Apress.

[30] Strudwick T. (2016). Soccer Science. Champaign, IL: Human Kinetics.

[31] Thevenet D, Tardieu M, Zouhal H, et al. (2007). Influence of exercise intensity on time spent at high percentage of maximal oxygen uptake during an intermittent session in young endurance-trained athletes. Eur J Appl Physiol, 102 (1), 19-26. Doi:https://doi.org/10.1007/s00421-007-0540-6

[32] TRISHA D. S, STEPHAN V, PAUL B. H, WILLIAM S. FOSTER, and BRENDON J. G. (2016). The Effect of Training Intensity on $\mathrm{VO}_{2} \max$ in Young Healthy Adults: A Meta-Regression and Meta-Analysis. Int J Exerc Sci, 9 (2), 230-247. Retrieved from https://www.ncbi.nlm.nih.gov/p mc/articles/PMC4836566/

[33] Youlian Hong. (2014). Routledge Handbook of Ergonomics in Sport and Exercise. London: Routledge.

[34] Zerf M, Houwar A, Mime M, Bengoua A. (2016). Height versus Weight which Cassel Parameter Determine Pulmonary Functions Fitness among the Algerians Soccer Players. J Pulm Respir Med, 6 (353). Doi:10.4172/2161-10 5X.1000353

[35] Zerf M. (2017). Influence of maximum heart rate predicts method on appropriate exercise intensity via Algerian soccer training programs. Turkish Journal of Sport and Exercise, 254-260. Doi:http://dx.doi.org/10.15314/tsed.32 3317

[36] Zerf M. (2018). Aerobic Fitness as a Superior Predictor Factor to Estimate the Optional Body Weight among the Soccer Players. 2:. J. Hum Bio \& Health Edu, 2, 010. Retrieved from https://bioaccent.org/humanbiology-health education/humanbiology-healtheducation10.php

[37] zerf, M. (2018). Main Goalkeeper versus his Substitute: which criteria limit the traditional method of selecting the potential goalkeepers? Pamukkale Spor Bilimleri Dergisi, 11-22. doi: Retrieved from http://dergipark.gov.tr/psbd/iss ue/39562/329423

[38] Zouhal H. Ghamel E, LeMoal G. Wong G, BenOunis O, Castagna G, Duluc G, Owen A.L. and Drust B. (2013). Physiological Responses of General vs. Specific Aerobic Endurance Exercises in Soccer. Asian J Sports Med, 4 (3), 213-220. Retrieved from https://www.ncbi.nlm.nih.gov/p mc/articles/PMC3880666/ 